\title{
Plant Growth Regulators Application Enhance Tolerance to Salinity and Benefit the Halophyte Plantago coronopus in Saline Agriculture
}

\author{
Milagros Bueno ${ }^{1, *(D)}$ and María del Pilar Cordovilla ${ }^{1,2}$ (D) \\ 1 Plant Physiology Laboratory, Department Animal Biology, Plant Biology and Ecology, Faculty of \\ Experimental Science, University of Jaén, Paraje Las Lagunillas, E-23071 Jaén, Spain; mpilar@ujaen.es \\ 2 Center for Advances Studies in Olive Grove and Olive Oils, Faculty of Experimental Science, \\ University of Jaén, Paraje Las Lagunillas, E-23071 Jaén, Spain \\ * Correspondence: mbueno@ujaen.es; Tel.: +34-953-212-140
}

check for updates

Citation: Bueno, M.; Cordovilla, M.d.P. Plant Growth Regulators Application Enhance Tolerance to Salinity and Benefit the Halophyte Plantago coronopus in Saline

Agriculture. Plants 2021, 10, 1872. https: / / doi.org/10.3390/ plants10091872

Academic Editors: Juan Barceló, Oscar Vicente and

Marius-Nicusor Grigore

Received: 6 August 2021

Accepted: 7 September 2021

Published: 10 September 2021

Publisher's Note: MDPI stays neutral with regard to jurisdictional claims in published maps and institutional affiliations.

Copyright: (c) 2021 by the authors. Licensee MDPI, Basel, Switzerland. This article is an open access article distributed under the terms and conditions of the Creative Commons Attribution (CC BY) license (https:/ / creativecommons.org/licenses/by/ $4.0 /)$.

\begin{abstract}
Climate change, soil salinisation and desertification, intensive agriculture and the poor quality of irrigation water all create serious problems for the agriculture that supplies the world with food. Halophyte cultivation could constitute an alternative to glycophytic cultures and help resolve these issues. Plantago coronopus can be used in biosaline agriculture as it tolerates salt concentrations of $100 \mathrm{mM} \mathrm{NaCl}$. To increase the salt tolerance of this plant, plant growth regulators such as polyamine spermidine, salicylic acid, gibberellins, cytokinins, and auxins were added in a hydroponic culture before the irrigation of $\mathrm{NaCl}(200 \mathrm{mM})$. In 45-day-old plants, dry weight, water content, osmolyte (sorbitol), antioxidants (phenols, flavonoids), polyamines (putrescine, spermidine, spermine (free, bound, and conjugated forms)) and ethylene were determined. In non-saline conditions, all plant regulators improved growth while in plants treated with salt, spermidine application was the most effective in improving growth, osmolyte accumulation (43\%) and an increase of antioxidants (24\%) in P. coronopus. The pretreatments that increase the sorbitol content, endogenous amines (bound spermine fraction), phenols and flavonoids may be the most effective in protecting to P. coronopus against stress and, therefore, could contribute to improving the tolerance to salinity and increase nutritional quality of $P$. coronopus.
\end{abstract}

Keywords: antioxidants; climate change; growth; osmolyte accumulation; phytohormones; polyamines; salicylic acid; biosaline agriculture; salt tolerance

\section{Introduction}

The increase in the world's population, intensive agriculture, poor quality irrigation water, the decrease in the amount of arable land, desertification, soil salinization, and climate change are all factors that have provoked a decrease in crop quality and yields; therefore, application of innovative techniques could improve crop performance [1-3]. Glycophytes are normally used in agriculture, but in a saline environment, they are subjected to osmotic stress and ionic toxicity, factors that negatively affect germination, growth, and crop yield; thus, identifying alternative salt-tolerant crops that can facilitate ecological rehabilitation and restoration and biosaline agriculture should be a priority research area in current agriculture (http:/ / www.sussex.ac.uk/affiliates/halophytes, accessed on 14 June 2021) [4]. Plants halophytes thrive in saline habitats, and can survive in extreme conditions (arid inlands, subtropical habitats, and temperate zones) [5,6]; in addition, these plants possess a series of strategies at anatomical, morphological, physiological, biochemical, and genetic level that allow them to survive to different habitats $[7,8]$. These strategies are wideranging and include phenotypic plasticity, dilution or salt excretion (succulence, salt glands, bladder hairs), decreased transpiration, stomatic and $\mathrm{CO}_{2}$ resistance control, water-use efficiency, C3-C4-CAM pathway, high $\mathrm{K}^{+} / \mathrm{Na}^{+}$compartmentalization (through the $\mathrm{Na}^{+} / \mathrm{H}^{+}$ 
antiporter of tonoplast and plasma membrane), osmolyte accumulation (polysaccharides, amino acids, polyols), antioxidant systems activation (for protection of photosynthetic apparatus, biomembranes and nucleic acids), the modulation of plant growth regulators, and the expression of certain gene (up-regulating osmolytes and antioxidants) that allows them to survive in a wide variety of environmental conditions [7-11]. On the other hand, halophytes can be used directly as a possible alternative to glycophytes, biofuel-producing crops, fodder and animal feeds, oilseeds and proteins crops, medicinal plants, and in phytoremediation [12-19]. Biosaline agriculture has three main advantages: the recovery of saline and degraded soils, its ability to use wastewater from agriculture, and the increase in the production of metabolites with better nutritional quality [12-14,16-20].

In general, plant growth regulators (PGRs) are used to improve crop production and increase to abiotic stress tolerance in glycophytes [21,22]. In saline conditions, PGRs could improve halophytes tolerance for a better crop production. Nevertheless, little is known about PGRs in halophytes and their responses to abiotic stress [23]. These compounds modulate different stages from seed germination to fruit development, ripening and senescence. They also are related to abiotic stress tolerance, and regulate the root: shoot ratio, control stomatal resistance, regulate antioxidant enzymes, delay leaf senescence and act as signal molecules [21]. Auxins regulate cell elongation, vascular tissue development and apical dominance [24]. Cytokinins control cell division, chloroplast biogenesis, leaf senescence, shoot differentiation, anthocyanin production and photomorphogenic development [25]. Gibberellic acid induces seed germination, leaf and stem elongation, favours flowering and fruit development [26,27]. Polyamine application [putrescine (Put), spermidine (Spd), and spermine (Spm)] in agricultural crops serve to protect plants against stress, modulating the homeostasis of reactive oxygen species (ROS), regulating antioxidant systems, cation transport across plant membrane, osmoregulation, and directly or indirectly regulate gene expression [28,29]. Finally, salicylic acid treatment favours the accumulation of osmolytes, alleviates photosynthesis and enhance the upregulation of antioxidant systems in some species [30,31]. We focused our study of PGRs irrigation on the cultivation of Plantago coronopus, a halophyte native to the Mediterranean region (South Spain) [32].

Plantago coronopus L. (Family Plantaginaceae) inhabits marine cliffs, marshes, and endorheic basins at altitudes up to $800 \mathrm{~m}$ (a.s.l.). This halophyte is annual or biennial, with leaves with central veins arranged in basal rosettes measuring 2-20 cm length. Its flowers are produced in spikes and appear in April-October; its seeds are small and brown. It is typically found in saltmarshes in SE Spain [33]. This plant has photosynthesis pathway C3, osmolytes (sorbitol and proline) [34], and antioxidants (phenols and polyamines) [32]. Its mechanisms of tolerance to salinity have been investigated by several authors [32,34-36]. Transport of toxic ions $\left(\mathrm{Na}^{+}\right.$and $\left.\mathrm{Cl}^{-}\right)$to aerial part, and their accumulation in vacuole, in addition to osmotic adjustment in its cytoplasm due to high concentrations of osmolytes allow develop succulence and therefore tolerate a certain degree of salinity [34]. On the other hand, this halophyte is used in biosaline agriculture as its edible leaves are greatly appreciated in salads due to their mild salty taste, crunchy texture, and excellent nutritional value [high content of phenols, amino acids (phenylalanine, tyrosine) and minerals (potassium, calcium, magnesium, sodium, etc.). Plantago coronopus showed a higher chlorophyll and flavonoids contents when it was grown in a Se enriched medium. These microgreens showed better nutraceutical value. On the other hand, these herbs grown in the open air presented a better development that in greenhouses, demonstrating the potential of this halophyte in saline agriculture [20,35,37-41].

The following PGRs were added to a hydroponic culture of P. coronopus: auxins (indole-acetic acid), cytokinins (Kinetin), gibberellic acid $\left(\mathrm{GA}_{3}\right)$, polyamine (spermidine) and salicylic acid before $\mathrm{NaCl}(200 \mathrm{mM})$ application. After 21 days of growth in the absence or presence of salt, dry weight, water content, sorbitol, phenols, flavonoids, endogenous polyamines [putrescine, spermidine, spermine (free, conjugated and bound)], and ethylene were determined. We wanted to identify which PGRs produced the best results to investigate: (1) ways to improve its tolerance to salinity, (2) boost its growth, and (3) increase 
the nutritional quality of this species. The results could provide technical guidance for increasing the cultivation of this halophyte and the benefits that it provides.

\section{Results}

\subsection{Effect of Plant Growth Regulators (PGRs) Application on Growth of P. coronopus}

Previous works by our research group showed that P. coronopus seeds collected from Brujuelo saltmarsh in Jaén (Spain) and cultivated hydroponically showed similar dry weight at 0 and $100 \mathrm{mM} \mathrm{NaCl}$ and a decrease at $200 \mathrm{mM} \mathrm{NaCl}$ (whole plant) [32]. We decided to choose $0 \mathrm{mM}$ and $200 \mathrm{mM} \mathrm{NaCl}$ for the cultivation of this halophyte. Growth parameters such as dry weight and water content, at 45 days old, are shown in Table 1. In non-saline conditions, a positive effect on stem + leaves dry weight (SLDW) and root dry weight (RDW) was observed; being pretreatments Spd and SA $(p \leq 0.05)$ whose having the highest values, above all in RDW (A in Table 1). In the case of Spd, the increases in SLDW and RDW were $47 \%$ and $86 \%$, respectively. In water content Spd and SA also had the highest values of all studied pretreatments, especially in roots (increase of $9 \%$ compared to control). In saline pretreatments (B in Table 1), Kinetin + salt and Spd + salt obtained the best results for SLDW, while IAA + salt and Spd + salt had the best values for RDW. In the pretreatment Spd + salt the increases were 174\% and 197\% for SLDW and RDW, respectively, compared to the controls (salt). Growth with the treatments Kinetin + salt and Spd + salt are shown in Figure 1 .

Table 1. (A) Effect of PGRs (plant growth regulators) application in salt-free pretreatment, (B) effect of PGRs application under saline conditions $(200 \mathrm{mM} \mathrm{NaCl})$ in Plantago coronopus, at 45 days of culture on SLDW (stem + leaves dry weight), RDW (root dry weight), SLWC (stem + leaves water content), and roots water content (RWC). Means \pm SE $(n=16)$. Different letters within the same row represent significant differences between treatments, according to Tukey's test $(p \leq 0.05)$.

\begin{tabular}{|c|c|c|c|c|c|}
\hline A. & PGRs Application without Salt & $\begin{array}{l}\text { SLDW } \\
\text { (g/plant) }\end{array}$ & $\begin{array}{c}\text { RDW } \\
\text { (g/plant) }\end{array}$ & SLWC (\%) & RWC (\%) \\
\hline & Control (no PGR) & $0.134 \pm 0.0038^{\mathrm{c}}$ & $0.0198 \pm 0.0014^{b}$ & $94.16 \pm 0.47^{a}$ & $85.07 \pm 0.24^{\mathrm{c}}$ \\
\hline & IAA & $0.171 \pm 0.0056^{\mathrm{ab}}$ & $0.0321 \pm 0.0037^{\mathrm{a}}$ & $95.45 \pm 0.52^{\mathrm{a}}$ & $92.05 \pm 0.28^{a b}$ \\
\hline & Kinetin & $0.179 \pm 0.0062^{\mathrm{a}}$ & $0.0214 \pm 0.0016^{b}$ & $95.67 \pm 0.55^{\mathrm{a}}$ & $90.63 \pm 0.63^{a b}$ \\
\hline & $\mathrm{GA}_{3}$ & $0.147 \pm 0.0052^{b c}$ & $0.0199 \pm 0.0018^{b}$ & $95.51 \pm 0.46^{\mathrm{a}}$ & $89.80 \pm 0.47^{b}$ \\
\hline & Spd & $0.197 \pm 0.0089^{\mathrm{a}}$ & $0.0369 \pm 0.0021^{\mathrm{a}}$ & $95.91 \pm 0.56^{\mathrm{a}}$ & $92.88 \pm 0.66^{\mathrm{a}}$ \\
\hline & SA & $0.186 \pm 0.0063^{a}$ & $0.0341 \pm 0.0012^{\mathrm{a}}$ & $95.74 \pm 0.39^{a}$ & $92.53 \pm 0.45^{\mathrm{a}}$ \\
\hline B. & PGRs Application with Salt & $\begin{array}{c}\text { SLDW } \\
\text { (g/plant) }\end{array}$ & $\begin{array}{c}\text { RDW } \\
\text { (g/plant) }\end{array}$ & SLWC (\%) & RWC (\%) \\
\hline & Control (salt) & $0.080 \pm 0.0110^{\mathrm{d}}$ & $0.0101 \pm 0.0005^{\mathrm{d}}$ & $91.54 \pm 0.35^{b}$ & $82.63 \pm 0.33^{c}$ \\
\hline & IAA + salt & $0.132 \pm 0.0078^{b c}$ & $0.0167 \pm 0.0005^{b}$ & $92.50 \pm 0.38^{b}$ & $85.54 \pm 0.38^{a b}$ \\
\hline & Kinetin + salt & $0.161 \pm 0.0064^{\mathrm{b}}$ & $0.0128 \pm 0.0004^{\mathrm{c}}$ & $93.18 \pm 0.42^{b}$ & $83.55 \pm 0.90^{b c}$ \\
\hline & $\mathrm{GA}_{3}+$ salt & $0.085 \pm 0.0063^{\mathrm{d}}$ & $0.0117 \pm 0.0006^{\mathrm{cd}}$ & $92.11 \pm 0.52^{b}$ & $83.09 \pm 0.56^{b c}$ \\
\hline & Spd + salt & $0.219 \pm 0.0100^{\mathrm{a}}$ & $0.0300 \pm 0.0058^{\mathrm{a}}$ & $95.72 \pm 0.45^{\mathrm{a}}$ & $87.55 \pm 0.40^{\mathrm{a}}$ \\
\hline & SA + salt & $0.092 \pm 0.0090^{\mathrm{cd}}$ & $0.0094 \pm 0.0008^{\mathrm{d}}$ & $92.50 \pm 0.44^{b}$ & $82.43 \pm 0.70^{c}$ \\
\hline
\end{tabular}

\subsection{Effect of PGRs Application on Sorbitol Content}

It is well known that soluble carbohydrates (sorbitol) are plentiful in the family Plantaginaceae. For this reason, in the leaves of P. coronopus this osmolyte was analyzed at 45 days of culture. In pretreatments without salt (Figure 2A) no significant differences were found between PGR pretreatments compared to the control (without PGRs). However, in saline conditions the Spd + salt and Kinetin + salt had higher values $(p \leq 0.05)$ of osmolyte accumulation (Figure 2B), (increase 0.43 -fold and 0.33-fold) respectively, compared to untreated plants (without PGRs + salt). It should also be noted that in all pretreatments under both saline and non-saline conditions, sorbitol concentrations were high even in the control treatments (no PGRs) and (salt). 


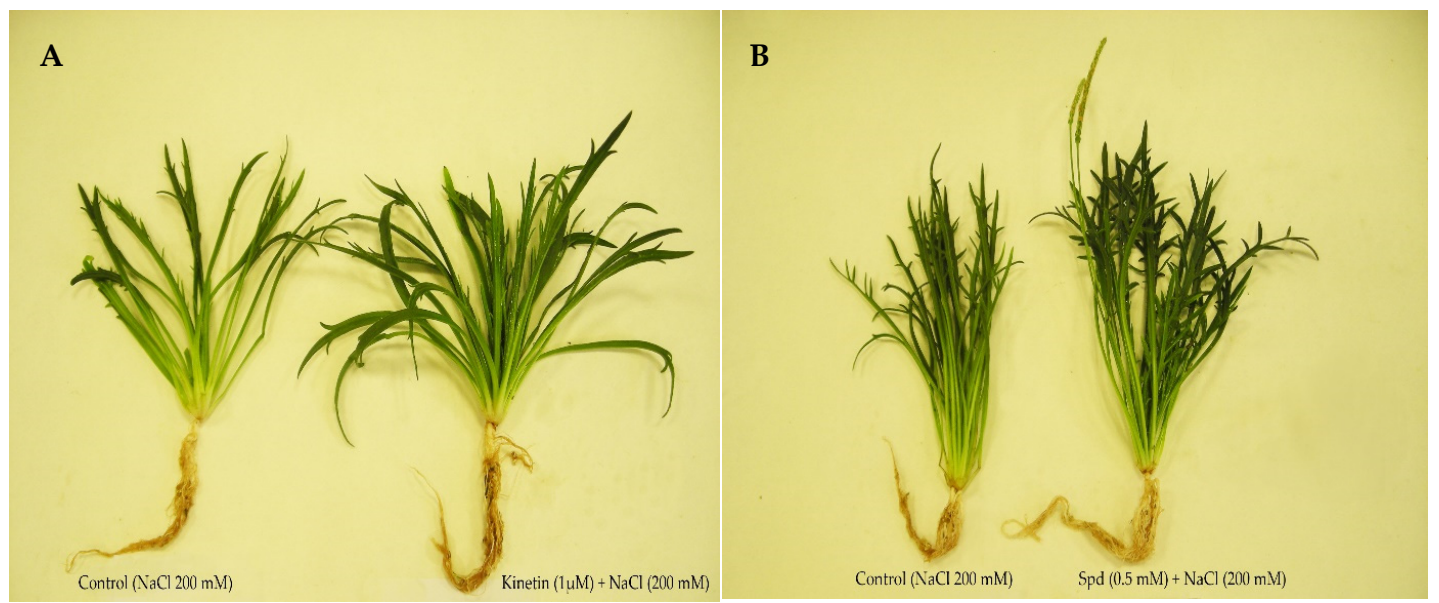

Figure 1. Plantago coronopus cultivated with Kinetin + salt compared to control (A), and P. coronopus cultivated with Spd + salt compared to control (B).
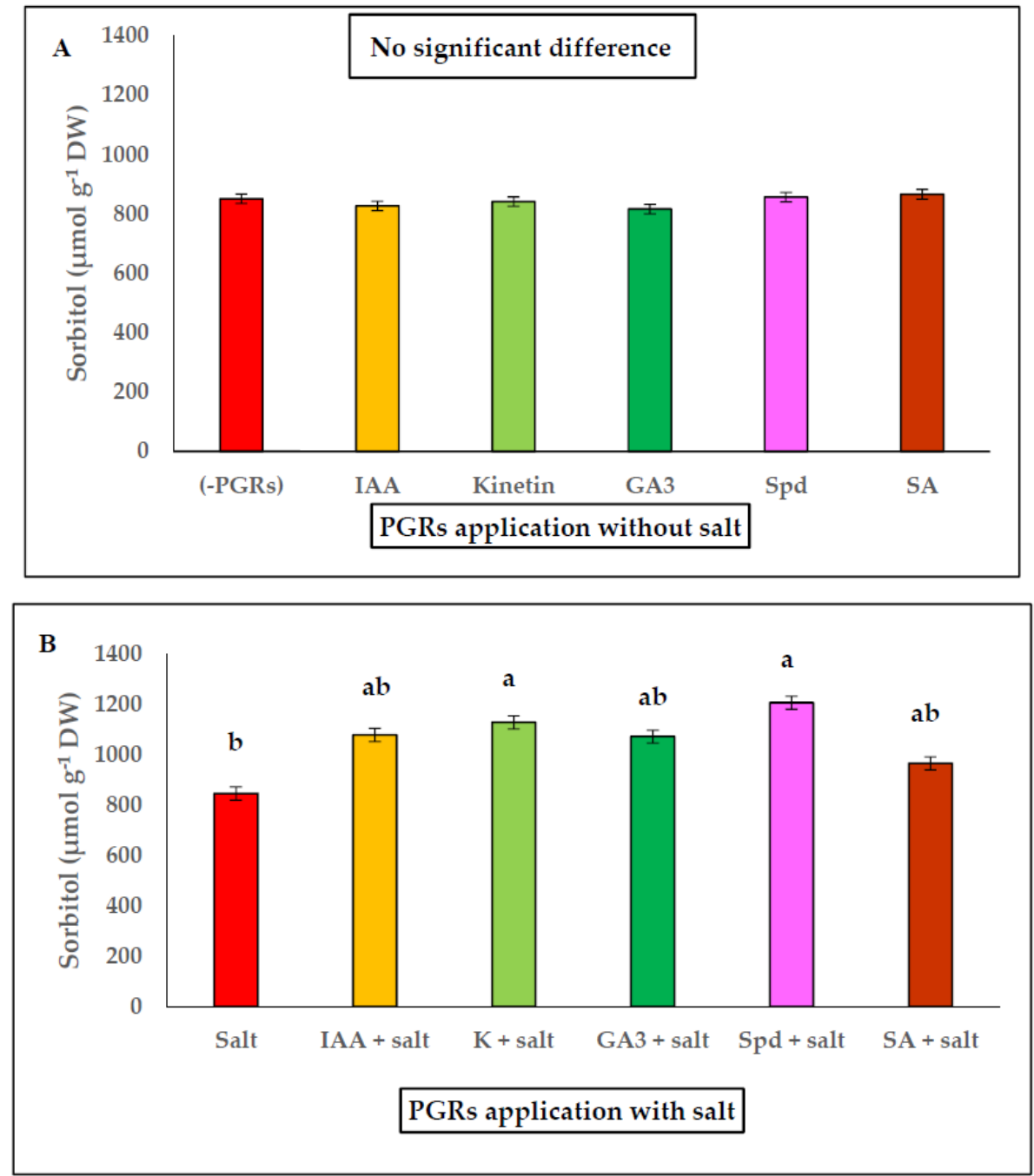

Figure 2. (A) Sorbitol content in P. coronopus leaves with the following PGRs: IAA, Kinetin, GA 3 , Spd, and SA compared to control (-PGRs). (B) Sorbitol content with PGRs in saline conditions: IAA + salt, Kinetin + salt, GA 3 + salt, Spd + salt, and SA + salt, compared with salt $(200 \mathrm{mM} \mathrm{NaCl})$. Means $\pm \mathrm{SE}(n=3)$. Different letters above bars represent significant difference between treatments $(p \leq 0.05)$. 


\subsection{Effect of PGRs Application on the Total Amount of Phenols and Flavonoids in} Saline Conditions

We studied the effect of PGRs application with salt on the antioxidant content (measured as total phenols and flavonoids) in the leaves of P. coronopus at 45 days of culture to observe whether any pretreatment PGRs increased phenols and flavonoids content. The results shown in Table 2 indicate that treatments with Kinetin + salt and Spd + salt significantly $(p \leq 0.01)$ increased the content of phenols and flavonoids by $24 \%$ compared to untreated plants (only salt). The values of phenols and flavonoids under non-saline conditions did not have relevant results or show any significant differences between pretreatments (data not shown).

Table 2. Effect of PGRs application with salt ( $200 \mathrm{mM} \mathrm{NaCl})$ in $P$. coronopus leaves, at 45 days old, on total phenols and flavonoids. The values represent means \pm SE $(n=3)$. The total phenols was expressed in mg gallic acid (GAE) per gr dry weight, and total flavonoids was expressed in mg of catechin (CE) per gr dry weight. Different letters within the same row represent significant difference among treatments, according to Tukey's test $(p \leq 0.01)$.

\begin{tabular}{|c|c|c|}
\hline PGRs Application with Salt & $\begin{array}{c}\text { Total Phenols } \\
\left(\mathrm{mg} \mathrm{GAE}^{-1} \mathrm{DW}\right)\end{array}$ & $\begin{array}{l}\text { Total Flavonoids } \\
\left.(\mathrm{mg} \mathrm{CE} \mathrm{g})^{-1} \mathrm{DW}\right)\end{array}$ \\
\hline Control (Salt) & $4.5 \pm 0.11^{c}$ & $3.1 \pm 0.11^{\mathrm{b}}$ \\
\hline IAA + salt & $4.9 \pm 0.12 \mathrm{bc}$ & $3.5 \pm 0.12^{\mathrm{ab}}$ \\
\hline Kinetin + salt & $5.3 \pm 0.10^{a b}$ & $3.7 \pm 0.23^{a b}$ \\
\hline $\mathrm{GA}_{3}+$ salt & $4.6 \pm 0.17^{b c}$ & $2.9 \pm 0.23^{b}$ \\
\hline Spd + salt & $5.9 \pm 0.21^{a}$ & $4.0 \pm 0.14^{\mathrm{a}}$ \\
\hline SA + salt & $5.0 \pm 0.20 \mathrm{bc}$ & $3.2 \pm 0.20^{b}$ \\
\hline
\end{tabular}

\subsection{Effect of PGRs Application on Endogenous Free, Bound and Conjugated Polyamines and Ethylene}

In general, the pretreatments Spd without salt, and Spd with salt gave the greatest growth results in P. coronopus. Therefore, we considered it necessary to analyze PGRs application on the endogenous PA content (free, bound and conjugated) in the absence or presence of salt. The data are shown in Figures 3-5. In salt-free PGRs pretreatment, endogenous Put, Spd, and Spm (free, bound, and conjugated forms) increased compared to the control (-PGRs); the pretreatments with Kinetin, Spd, and SA had the highest values for endogenous Put (Figure 3a), endogenous Spd (Figure 4a) and endogenous Spm (Figure 5a), which corresponded to a greater increase in DW and WC for P. coronopus. This increase mainly occurs in bound and free PA fractions. However, under saline conditions, PA levels are modulated by salt. We detected a decreased of endogenous Put (free, bound and conjugated) in pretreatments Kinetin + salt and Spd + salt (Figure 3b) compared to values in Figure 3a; nevertheless, no significant difference was observed in pretreatments with salt due to the low amount of Put detected. However, endogenous Spm did increase in free and, above all, bound forms (Figure 5b), and these values being always higher than observed in saline-free pretreatments. The most significant increase was observed for pretreatment Spd with salt: where endogenous Spm increased two-fold (free form), 2.7-fold (bound form) and 2-fold (conjugated form) compared to the control salt (Figure $5 b$ ). Therefore, pretreatments Spd + salt and Kinetin + salt decreased endogenous Put (free, bound and conjugated) and increased endogenous Spm content (above all endogenous Spm bound). In pretreatment Spd + salt the increase of endogenous Spm (bound fraction) (Figure $5 \mathrm{~b}$ ) was higher by 5.3-fold than endogenous Spm (bound fraction) in pretreatment Spd (Figure 5a). 

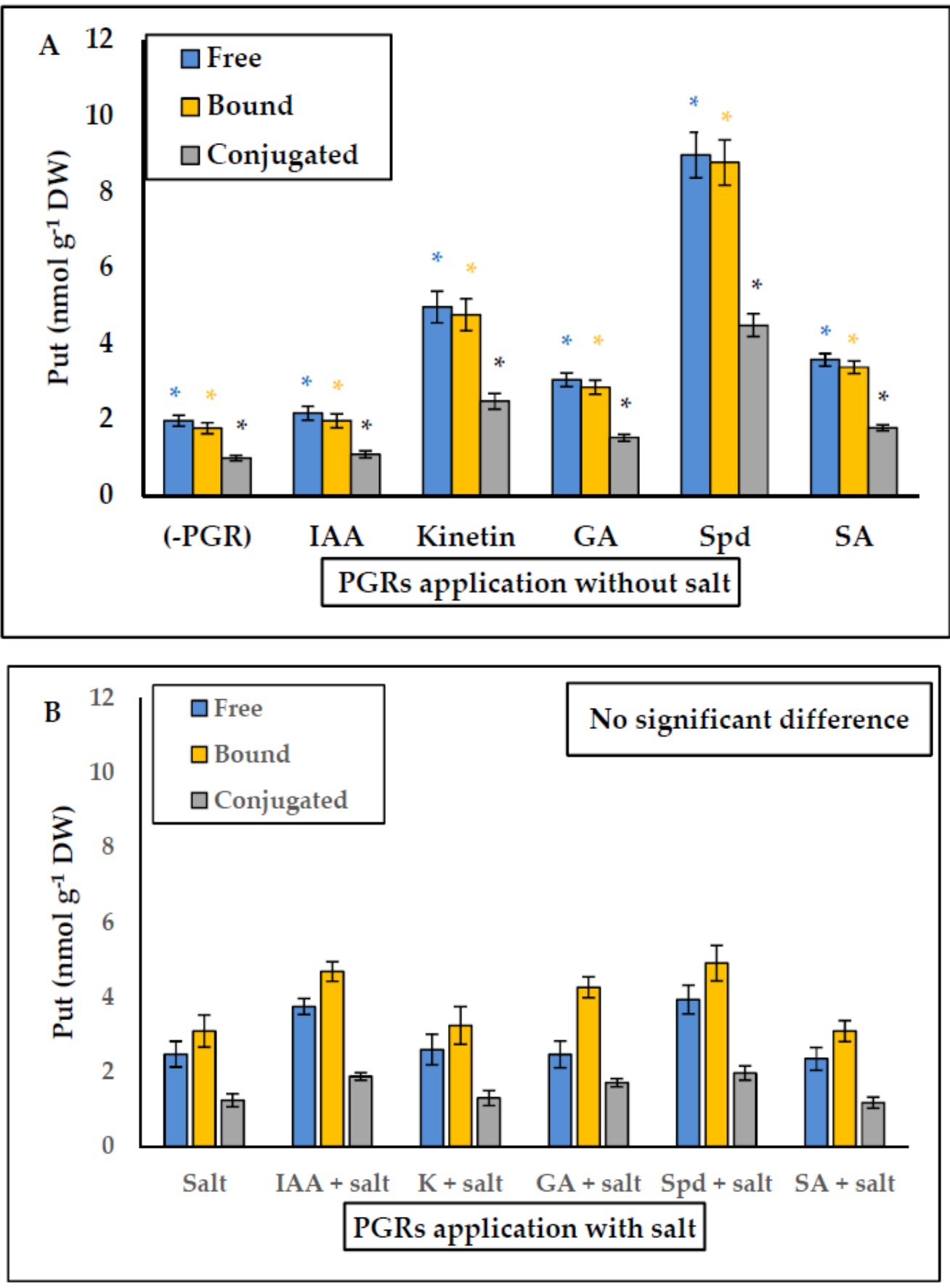

Figure 3. (A) Effect of PGRs application without salt, and (B) PGRs with salt (200 mM NaCl), in Plantago coronopus leaves at 45-day-old, on Putrescine (Free, Bound and Conjugated) content. Means \pm SE $(n=3)$. The asterisk above the column represents significant difference between treatments of free Put, significant difference between treatments of bound Put and significant difference between treatments of conjugated Put, according to Tukey's test $(p \leq 0.01)$. 

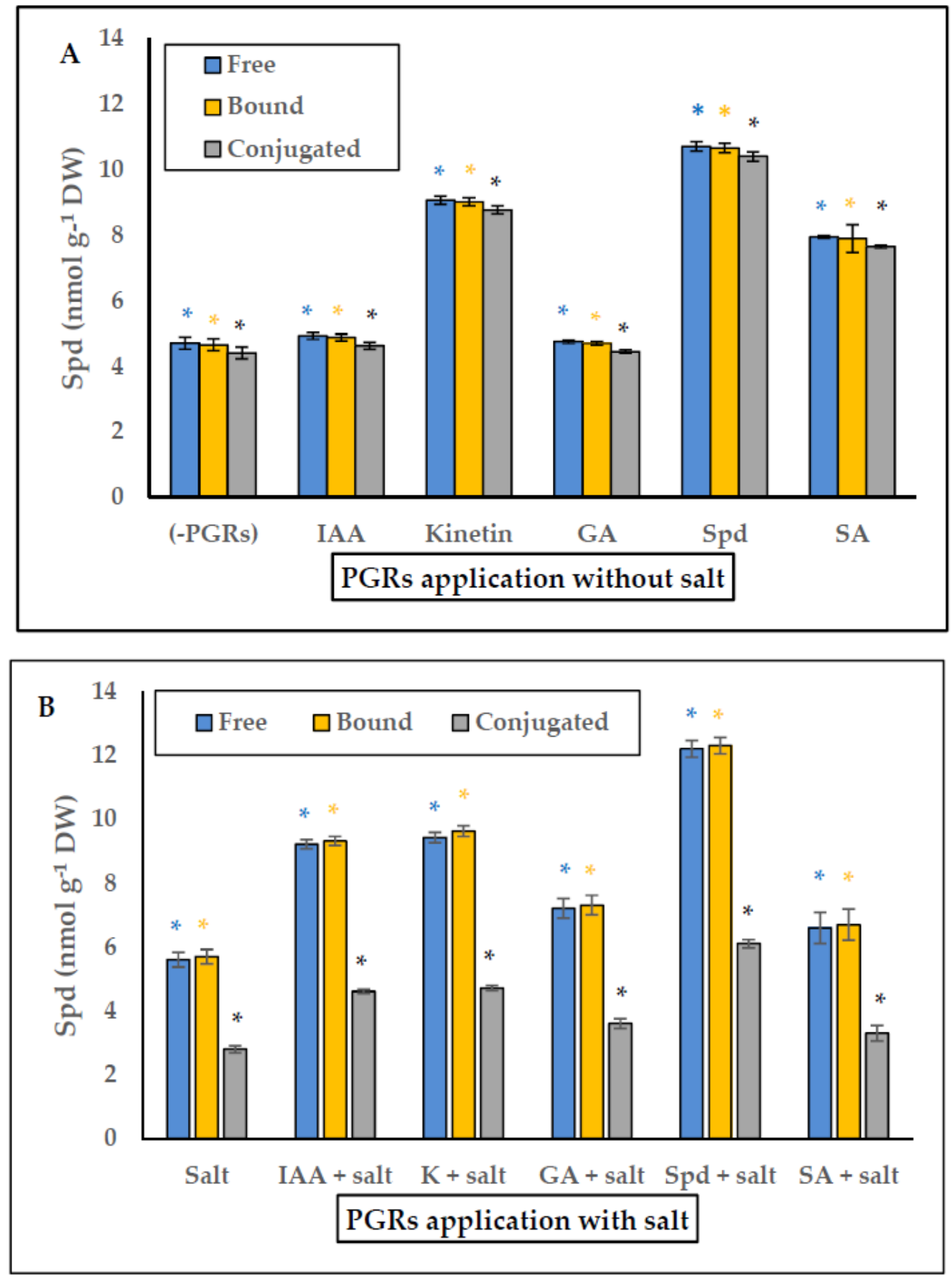

Figure 4. (A) Effect of PGRs application without salt, and (B) PGRs with salt (200 mM NaCl), in Plantago coronopus leaves at 45-day-old, on Spermidine (Free, Bound and Conjugated) content. Means \pm SE $(n=3)$. The asterisk above the column represents significant difference between treatment of free Spd, significant difference between treatments of bound Spd and significant difference between treatments of conjugated Spd, according to Tukey's test $(p \leq 0.01)$. 

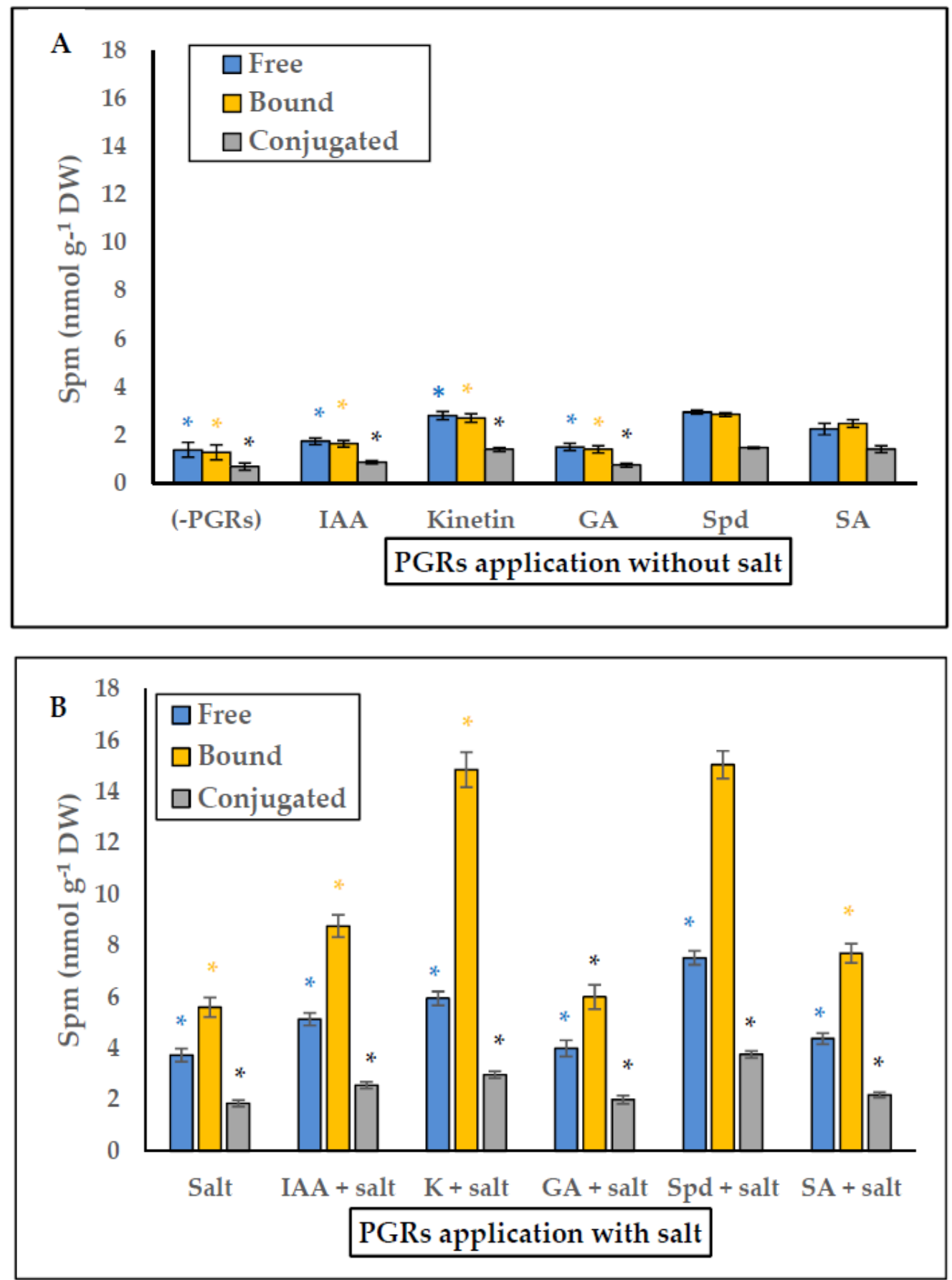

Figure 5. (A) Effect of PGRs application without salt, and (B) PGRs with salt (200 $\mathrm{mM} \mathrm{NaCl),} \mathrm{in} \mathrm{Plantago} \mathrm{coronopus} \mathrm{leaves}$ at 45-day-old, on Spermine (Free, Bound and Conjugated) content. Means \pm SE $(n=3)$. The asterisk above the column represents significant difference between treatments of free Spm, significant difference between treatments of bound Spm and significant difference between treatments of conjugated Spm, according to Tukey's test $(p \leq 0.01)$.

Table 3 shows total PAs (Put (free, conjugated and bound forms) + Spd (free, conjugated and bound forms) + Spm (free, conjugated and bound forms)) under saline and non-saline conditions. All pretreatments increased PA content, especially under saline conditions, the highest values being Spd - salt and Spd + salt. Ethylene production in the leaves of this halophyte were compared to the total PAs. The results indicated a decrease in ethylene production that may contribute to increase PA content due to sharing a common synthesis pathway that we explain in discussion. 
Table 3. (A) Effect of PGRs application without salt, and (B) PGRs with salt (200 mM NaCl) in P. coronopus leaves on total PAs [Put (Free, Bound and Conjugated) + Spd (Free, Bound and Conjugated $)+\operatorname{Spm}$ (Free, Bound and Conjugated)] and ethylene. Means \pm SE $(n=3)$. Different letters within the same row represent significant differences among treatments, according to Tukey's test $(p \leq 0.01)$.

\begin{tabular}{|c|c|c|c|}
\hline A. & PGRs Application without Salt & $\begin{array}{c}\text { Total PAs } \\
\left(\text { nmol } \mathrm{g}^{-1} \mathrm{DW}\right)\end{array}$ & $\begin{array}{c}\text { Ethylene } \\
\left(\mathrm{nL} \mathrm{g}^{-1} \mathrm{FW} \mathrm{h}^{-1}\right)\end{array}$ \\
\hline & Control (no PGRs) & $21.87 \pm 0.68^{\mathrm{d}}$ & $10.30 \pm 0.64^{a}$ \\
\hline & IAA & $24.54 \pm 0.75^{\mathrm{d}}$ & $8.35 \pm 0.61^{a b}$ \\
\hline & Kinetin & $46.00 \pm 1.81^{b}$ & $5.62 \pm 0.71^{b}$ \\
\hline & $\mathrm{GA}_{3}$ & $25.01 \pm 0.88^{d}$ & $7.68 \pm 0.67^{a b}$ \\
\hline & Spd & $61.29 \pm 1.45^{\mathrm{a}}$ & $6.35 \pm 0.53^{b}$ \\
\hline & SA & $36.50 \pm 0.69^{c}$ & $5.81 \pm 0.65^{b}$ \\
\hline B. & PGRs Application with Salt & $\begin{array}{c}\text { Total PAs } \\
\left.\text { (nmol } \mathrm{g}^{-1} \mathrm{DW}\right)\end{array}$ & $\begin{array}{c}\text { Ethylene } \\
\left(\mathrm{nL} \mathrm{g}^{-1} \mathrm{FW} \mathrm{h}^{-1}\right)\end{array}$ \\
\hline & Control (salt) & $32.11 \pm 0.58^{c}$ & $7.61 \pm 0.52^{a}$ \\
\hline & IAA + salt & $49.94 \pm 0.42^{b}$ & $3.30 \pm 0.68^{b}$ \\
\hline & Kinetin + salt & $54.70 \pm 2.42^{b}$ & $3.77 \pm 0.47^{\mathrm{b}}$ \\
\hline & $\mathrm{GA}_{3}+$ salt & $36.76 \pm 1.16^{c}$ & $5.23 \pm 0.59 \mathrm{ab}$ \\
\hline & Spd + salt & $67.79 \pm 2.54^{\mathrm{a}}$ & $3.74 \pm 0.64^{\mathrm{b}}$ \\
\hline & SA + salt & $37.50 \pm 1.94^{\mathrm{c}}$ & $5.76 \pm 0.53^{a b}$ \\
\hline
\end{tabular}

The correlation between Spm and sorbitol $(\mathrm{r}=0.8465 ; p \leq 0.01)$, the total PAs and Spd $(\mathrm{r}=0.9193 ; p \leq 0.01)$, the total PAs and Spm $(\mathrm{r}=0.7184 ; p \leq 0.01)$ were always positive. However, the negative correlation between ethylene $\left(\mathrm{C}_{2} \mathrm{H}_{2}\right)$ and $\mathrm{Spm}(\mathrm{r}=-0.732 ; p \leq 0.01)$ and ethylene and total PAs $(\mathrm{r}=-0.723 ; p \leq 0.01)$ indicated that these metabolites (sorbitol. Spd and Spm) are necessary, especially under saline conditions, for enhancing salt tolerance and mitigating the adverse effect of stress (Table 4).

Table 4. Simple correlation coefficient (Pearson method) among all parameters studied in saline and non-saline conditions in P. coronopus $\left(p \leq 0.05^{*} ; p \leq 0.01^{* *}\right)$.

\begin{tabular}{|c|c|c|c|c|c|c|c|c|c|c|}
\hline & SLDW & RDW & SLWC & RWC & SOR & PUT & SPD & SPM & Total PAs & $\mathrm{C}_{2} \mathrm{H}_{2}$ \\
\hline SLDW & 1 & & & & & & & & & \\
\hline RDW & $0.7522 * *$ & 1 & & & & & & & & \\
\hline SLWC & $0.7629 * *$ & $0.7559 * *$ & 1 & & & & & & & \\
\hline RWC & 0.7049 ** & $0.8769 * *$ & $0.7941^{* *}$ & 1 & & & & & & \\
\hline SOR & 0.0723 & -0.2711 & -0.2874 & $-0.440^{* *}$ & 1 & & & & & \\
\hline PUT & $0.4624^{* *}$ & $0.4943^{* *}$ & 0.3212 & $0.4720 * *$ & -0.0267 & 1 & & & & \\
\hline SPD & $0.6824 * *$ & $0.4669 * *$ & $0.3550 *$ & $0.3892 *$ & $0.3662 *$ & $0.7729 * *$ & 1 & & & \\
\hline SPM & 0.1200 * & -0.3134 & -0.3501 * & $-0.470 * *$ & $0.8465^{* *}$ & -0.0308 & $0.4360 * *$ & 1 & & \\
\hline Total PAs & $0.5148^{* *}$ & 0.2064 & $0.0816^{*}$ & 0.0840 & $0.5897^{* *}$ & $0.6838^{* *}$ & $0.9193 * *$ & $0.7184^{* *}$ & 1 & \\
\hline $\mathrm{C}_{2} \mathrm{H}_{2}$ & -0.2150 & 0.1044 & 0.2573 & 0.1496 & $-0.659^{* *}$ & -0.2616 & $-0.588^{* *}$ & $-0.732^{* *}$ & $-0.723^{* *}$ & 1 \\
\hline
\end{tabular}

Parameters studied: SLDW (stem + leaf dry weight); RDW (root dry weight); SLWC (stem + leaf water content); RWC (root water content); SOR (sorbitol); PUT (Free + Bound + Conjugated); SPD (Free + Bound + Conjugated); SPM (Free + Bound + Conjugated); Total PAs (Total PUT + Total SPD + Total SPM); $\mathrm{C}_{2} \mathrm{H}_{2}$ (ethylene production).

\section{Discussion}

The benefits that PGRs application have on growth and abiotic stress are well known [42-44]. Under saline conditions, PGRs alleviate the adverse effects of salt on morphological, physiological, biochemical characteristics, and on crop yields and quality $[10,29,45]$.

Previous studies showed a fall in dry weight at $200 \mathrm{mM} \mathrm{NaCl}$ in P. coronopus [32]. This species is in fact less salt-tolerant that other halophytes such as Frankenia pulverulenta and 
Atriplex prostrata that also grow in the Brujuelo saltmarsh (Jaén, Spain) [32]. In salt-free pretreatment PGR, the dry weight and water content were increased in P. coronopus, especially under pretreatments Spd, SA, and Kinetin in aerial parts and Spd, SA, and IAA in roots (A in Table 1). More specifically, PAs such as Spd are aliphatic biogenic amines. These amines serve as an $\mathrm{N}$ reserve for the plant, N:C ratio regulate, favour synthesis of pigments photosynthetic, acid nucleic and proteins. Spermidine applications elevate levels of endogenous PA, but the enzymes involved in its biosynthesis can be increased without altering PA degrading enzymes, such as occurs in zoysia grass subjected to saline stress [46], and therefore these triamine could improve photosynthetic activity and protein synthesis favouring the growth of P. coronopus [28,47,48]. On the other hand, SA is a phenolic secondary metabolite, although is more related to abiotic stress tolerance and defensive responses against pathogens, application SA can have beneficious effect on cell and vegetative growth, photosynthesis, and flowering in this halophyte [49]. Regarding auxins and CKs stimulating elongation, cell division, formation of roots, leaves elongation, chloroplast differentiation and photosynthesis, however, a partial effect on growth (IAA stimulated roots and Kinetin stimulated the aerial part) was observed in P. coronopus. Crosstalk interaction with other phytohormones, as well as signaling network are very complex. On the other hand, CKs and auxins can have antagonistic effect at low to medium concentration, and only at higher concentration they have adjunctive effect $[24,50]$. With respect to gibberellins, little effect has in this halophyte, so the effect of each treatment may be genotype-dependent [48]. In saline conditions, the pretreatment Spd with salt was the most effective both in terms of dry weight and water content (B in Table 1). At cellular level, PAs can act as a compatible solute, as scavengers of free radicals, regulate plant membrane transport and act as a signal molecule during stress response [28,51-53]. In plant growth, PAs can offer specific protection to the photosynthetic apparatus (structural organization and functional activity of thylakoids), stabilization of biomembranes, and homeostasis redox [54]. A positive effect on photosynthetic activity and uptake of water seems to occur in P. coronopus when Spd was applied (Figure 1). Few studies have ever examined PAs in other halophytes. In crops with high nutritional values such as quinoa (Chenopodium quinoa), PAs (especially, an increase in Spd and Spm under saline conditions) may be useful markers of salt-tolerant genotypes $[55,56]$ and may exert a protective effect improving growth on Cymodocea nodosa [57] and Solanum chilense [58]. Specifically, exogenous application of Spd in C. nodosa improving chlorophyll fluorescence levels under different saline treatments, maintaining the photosynthetic apparatus functional, under long-term hypo-osmotic stress [57]. Nevertheless, the positive effect of PAs may vary depending on the type of biotic and abiotic stress, plant species, time of exposure and physiological status of the tissues/organs $[59,60]$, and therefore the effect of pretreatments must be studied in each halophyte.

Halophytes (dicotyledonous) accumulate inorganic ions (mainly $\mathrm{Na}^{+}, \mathrm{Cl}^{-}$) in their aerial parts and excrete excess salt through saline glands, bladder hairs or by developing succulence in their leaves [61]. For this reason, we focused our studies on P. coronopus leaves. In previous studies, we detected a high concentration of ions $\left(\mathrm{Na}^{+}, \mathrm{Cl}^{-}\right)$related to a certain degree of succulence [32]. Al-Hassan et al. [34] concluded that family Plantaginaceae have a "constitutive mechanism" of tolerance in which the transport of $\mathrm{Na}^{+}$and $\mathrm{Cl}^{-}$ions (inorganic osmolytes) to the leaves and compartmentalization in the vacuole, contribute to cellular osmotic balance, and increase antioxidant metabolism under saline stress [34,36]. Polyamines are related to ionic transport through at membrane thylakoid, tonoplast, and plasma membranes $[52,62,63]$. Pottosin and Shabala showed that exogenous PAs application (0.1-1 mM) activated $\mathrm{Ca}^{2+}$ efflux, net $\mathrm{H}^{+}$fluxes, and activated $\mathrm{H}^{+}$-ATPase pump under stress, but all these experiments were realized in the roots of glycophyte seedlings [52,62,63]. There are no studies on the application of PAs in halophytes on membrane ion channels. Nevertheless, irrigation for 10 days with PGRs (in saline and non-saline conditions) did not modify significantly ionic content and the "pre-adaptation" to stress proposed by Al-Hassan et al. [34] in P. coronopus (therefore ion data were not included). On the other 
hand, the osmoprotective compounds (proline, glycine-betaine, sugar, and polyols) favor water uptake, act as chaperons to molecular stabilized proteins and membranes, scavenge ROS, and/or protect antioxidant enzymes [64,65]. The family Plantaginaceae preferably accumulates sugars and polyols, sorbitol being the most abundant soluble carbohydrate in all Plantago species [66]. Sorbitol accumulation and synthesis is carried out above all under anaerobic conditions such as those present in saltmarshes, with confers on the competitive advantages in the environments in which this halophyte normally grows (e.g., saltmarshes in Jaén, Spain) [32,34]. In P. coronopus, sorbitol was found in high concentrations in both saline and non-saline PGR pretreatments (Figure 2), although in pretreatments with salt, the Spd had higher values according to higher increase in dry mass and water content. The osmolyte content is probably modulated by PGRs in saline conditions. Pretreatment PGRs stimulate growth probably because they increase photosynthetic activity (above all pretreated with Kinetin and Spd) and increase the sugar content; of these sugars sorbitol plays the role of osmolyte in Plantago species growing in adverse environmental conditions. Sorbitol acts to maintain osmotic homeostasis, scavenging ROS, can regulate the osmotic balance, and sequester $\mathrm{Na}^{+}$in the vacuole or apoplast alleviating the toxic effect of saline stress on P. coronopus [34]. On the other hand, CKs and PAs mutually regulate different physiological and biochemical processes with strong correlations between CK and PA levels, and act as inter- and intracellular messengers regulating abiotic stress [67].

The selection of productive, fast-growing halophytes with high saline tolerance that give high yields is of vital importance if agriculture is to be successful. Plantago coronopus is a source of valuable secondary metabolites of great economic value [37]. Antioxidants such as phenols and flavonoids are an essential part of the human diet and so we used different PGR pretreatments to analyze these two metabolites under saline conditions (Table 2). Previous studies have demonstrated an increase in total phenols as $\mathrm{NaCl}$ application increases [32]. These bioactive molecules eliminate large amounts of ROS and protect the cell against oxidative stress on its lipids, proteins, and DNA, in addition act as hydrogen donors, single oxygen quenchers and reducing agents $[32,65,68]$. The experiments by Boestfleisch et al. [20] have shown that it is possible to manipulate a plant's antioxidant capacity by modifying the saline growth environment, and the development stage. Our results indicate that mixing Spd with salt significantly improved the content of phenol and flavonoids when compared to untreated plants (only salt). Wild edible plants tend to have higher micronutrient contents and secondary metabolites than those of domestication varieties, therefore $P$. coronopus cultivation irrigated with Spd with salt can increase metabolite contents and constitute a good a source of sugar, minerals, vitamins, and antioxidants, might provide health benefits, and could be used as a new gastronomic food [69-71].

The best treatment under both non-saline and saline conditions was the PA Spermidine. Thus, we decided to analyze the endogenous PA content in this halophyte. In the biosynthetic pathway precursors of diamine Put are ornithine and arginine, while the triamine Spd and tetramine Spm are produced by addition of aminopropyl groups from S-adenosyl methionine (SAM) that are sequentially incorporated to Put and Spd by enzymatic reactions catalyzed, respectively, by Spd synthase and Spm synthase. The SAM is decarboxylated by SAMDC (S-adenosyl-methionine decarboxylase) $[28,47,53]$. Currently, little is known about the endogenous content of PAs in halophytes. Only thirteen halophytes have been studied and PAs have been associated with saline excretion, ionic balance, osmoregulation, protective role on photosynthetic apparatus and biomembranes, high photochemical efficiency in photosystem II, and an increased antioxidant defence system [32,72]. The low levels of free PAs (Put, Spd and Spm) detected under saline conditions in P. coronopus [32] made it interesting to study the interconversion between different PA forms under treatment with PGRs. Polyamines can exist in free soluble forms, conjugated to hydroxycinnamic acids (small molecules), or bound to macromolecules such as DNA, lipids, and proteins [51]. In the vegetative stage, salt modulated PA levels, decreased Put content, and increased free and bound forms of Spd and Spm, with values that were always 
higher than under non-saline conditions. It is interesting underline the drastic increase in bound $>$ free $>$ conjugated Spm forms compared to endogenous Spm (free, bound, and conjugated) in non-saline conditions in pretreatment Spd + salt and pretreatment Spd (Figure 5A,B). We hypothesize that bound forms (above all in Spd pretreatments) can be related to the protection of endogenous cellular structures (mainly biomembranes and photosynthetic apparatus), such as occur in the halophyte Inula crithmoides [54]. In addition, Spd treatment increases it endogenous content and enhance also endogenous Spm. More specifically, bound Spd and Spm forms were detected in PSII and LHCII (light-harvesting antenna complex) [73,74]. There are no studies on halophytes, but the exogenous Spd application in some glycophytes showed stabilization of PSII, improving photosynthetic performance and the antioxidant system in chloroplasts under saline conditions [74-76]. We consider that similar effects can occur in P. coronopus when Spd is applied. At the level of transgenic plants, the Spd synthase gene (EsSPDS1) (an enzyme that synthesizes Spd and increase the content of endogenous Spd and Spm) was cloned and characterized in the obligate halophyte Eutrema salsugineum and inserted into transgenic tobacco plant subjected to water and salinity stress. The results showed lower malondialdehyde (MDA, oxidative stress indicator) levels, less ion leakage and ROS levels, which indicates better protection in biomembranes, higher water content and more antioxidant enzymes than in non-transformed plants [77]. Clearly, Spd application improves stress tolerance, probably by protecting membranes and photosynthetic apparatus, and decreasing ROS, which could explain our results regarding the enhanced salinity tolerance in P. coronopus.

Ethylene and PAs have a common precursor, SAM. The increase of total PAs was accompanied by a decrease in ethylene production under different PGR treatments, which could contribute to PA accumulation (Table 3), thereby indicating a certain competition between PAs and ethylene for SAM, the common precursor. Therefore, SAM can be derivative to the formation of PAs, above all, during salt stress [78,79]. The correlation coefficient between studied parameters (Table 4) confirms our results. Finally, studies in transgenic Arabidopsis plants (with overexpression of SAMDC and, therefore, with high levels of Spd and Spm) under abiotic stress revealed better growth, maintaining higher photosynthetic activity, higher $\mathrm{Fv} / \mathrm{Fm}$ and an increase in the $\mathrm{P}_{\mathrm{ABS}}^{\mathrm{I}}$ (Performance Index Based on Absorption). The enhancement in $\mathrm{P}^{\mathrm{I}} \mathrm{ABS}$ caused a higher efficiency of quantum yield and specific energy fluxes of PSII, and also higher activities of antioxidant enzymes were found in the transformed plant [80].

\section{Materials and Methods}

\subsection{Plant Material and Growth Conditions}

Seeds of P. coronopus were randomly collected in September 2016 from Brujuelo saltmarsh (GPS location: $37^{\circ} 52^{\prime} 46^{\prime \prime} \mathrm{N}, 3^{\circ} 40^{\prime} 11^{\prime \prime} \mathrm{W}$ ) (province of Jaén, Spain). Seeds were kept dry at $4{ }^{\circ} \mathrm{C}$ before being washed with sterile distilled water and sown in Petri dishes at $25 \pm 1{ }^{\circ} \mathrm{C}$ and a photoperiod of $16 \mathrm{~h}$ [32]. After 10 days, the most uniform seedlings were transferred to $1.5 \mathrm{~L}$ pots with vermiculite as a substrate. Four seedlings per pot were sown and hydroponically cultivated using Hoagland nutrient solution $50 \% \mathrm{pH} 6.5 \pm 0.1$ [81]. Plants were watered every two days with Hoagland nutrient solution. The environmental conditions in the growth chamber were the followings: photosynthetic photon flux density (PPFD) $500 \mu \mathrm{mol}$ photon $\mathrm{m}^{-2} \mathrm{~s}^{-1}, 400-700 \mathrm{~nm}$, provided by Sylvania Inc., Danvers, MA, USA, lamps, photoperiod $16 \mathrm{~h} / 8 \mathrm{~h}$ in a day/night cycle, temperature (day) $25^{\circ} \mathrm{C} \pm 1{ }^{\circ} \mathrm{C}$ and (night) $16^{\circ} \mathrm{C} \pm 1{ }^{\circ} \mathrm{C}$, and relative humidity of $55-75 \%$.

\subsection{Experimental Design and Treatments with PGRs and $\mathrm{NaCl}$}

In a growth chamber, plants were acclimated (in hydroponic conditions) for two weeks. Subsequently, these plants were treated for 10 days with different growth regulators applied to the nutrient solution when watered. The growth regulators used were the following: auxin: IAA; cytokinin: kinetin; gibberellins: $\mathrm{GA}_{3}$; polyamine: $\mathrm{Spd}$; and salicylic acid: SA. 
Six treatments were established with six pots for each treatment PGRs

1. No PGRs

2. IAA $(1 \mu \mathrm{M})$

3. Kinetin $(1 \mu \mathrm{M})$

4. $\mathrm{GA}_{3}(1 \mu \mathrm{M})$

5. $\quad$ Spd $(0.5 \mathrm{mM})$

6. SA $(0.5 \mathrm{mM})$

Six treatments were established with six pots for each treatment PGRs + salt

7. $\mathrm{NaCl}(200 \mathrm{mM})$

8. $\quad$ IAA $(1 \mu \mathrm{M})+\mathrm{NaCl}(200 \mathrm{mM})$

9. Kinetin $(1 \mu \mathrm{M})+\mathrm{NaCl}(200 \mathrm{mM})$

10. $\mathrm{GA}_{3}(1 \mu \mathrm{M})+\mathrm{NaCl}(200 \mathrm{mM})$

11. $\quad$ Spd $(0.5 \mathrm{mM})+\mathrm{NaCl}(200 \mathrm{mM})$

12. $\mathrm{SA}(0.5 \mathrm{mM})+\mathrm{NaCl}(200 \mathrm{mM})$

Subsequently, these pots were irrigated with two concentrations of $\mathrm{NaCl}: 0 \mathrm{mM}$ (treatment 1-6) and $200 \mathrm{mM}$ (treatment 7-12). NaCl levels were selected according to previous experiments realized by us [32]. To avoid osmotic shock, $\mathrm{NaCl}$ were increased progressively until the final required concentration was reached [32]; After 21 days in saline or non-saline conditions, plants were harvested for further analysis. Plants were 45 days old when harvested (14 days acclimation in pots, then 10 days of pretreatment with PGRs, and finally 21 days under saline or non-saline conditions). Flowering in this halophyte began approximately at $40-45$ days old.

\subsection{Growth Parameters}

The following parameters were determined: fresh weight (FW) (roots, stems, and leaves), dry weight (DW) (leaves + stems and roots), and water content (WC) (leaves + stems and roots). To obtain DW, plants were placed in a forced-air oven at $70 \mathrm{v}{ }^{\circ} \mathrm{C}$ for $72-96 \mathrm{~h}$ until a constant weight was obtained. This material was used to determine sorbitol, phenols, flavonoids, and endogenous PAs (free, conjugated and bound). Water content was calculated following the formula: $\mathrm{WC}(\%)=(\mathrm{FW}-\mathrm{DW} / \mathrm{FW}) \times 100$, where $\mathrm{SL}=$ stem and leaves, and $\mathrm{R}=$ Roots [82]. In fresh material (leaves), the ethylene production was determined.

\subsection{Sorbitol Quantification}

Sorbitol (Sor) was analyzed following Hassan et al. [34] for P. coronopus leaves (mature plants). For $10 \mathrm{~min}$, dry leaves (45-day-old) were boiled in milliQ water and subsequently filtered with filters $(0.22 \mu \mathrm{m})$. Afterwards, all samples (grown in absence and presence of salt) were injecting $(20 \mu \mathrm{L})$ in a Waters 717 autosampler into a Prontosil 120-3-amino column $(4.6 \times 125 \mathrm{~mm} ; 3 \mu \mathrm{m}$ particle size $)$. The conditions of isocratic flux were: $(1 \mathrm{~mL} / \mathrm{min})$ of $85 \%$ acetonitrile for $25 \mathrm{~min}$ in each run. Sor integration peaks were obtained in the Waters Empower software and the quantification was realized compared with the standard calibration curve. A Waters 1525 HPLC (high-performance liquid chromatography) coupled with a 2424 evaporative light scattering (ELS) detector (Markham, ON, Canada) were used to determinate Sor content. The source parameters of ELSD were gain 75, data rate 1 point per second, nebulizer heating $60 \%$, drift tube $50{ }^{\circ} \mathrm{C}$, and gas pressure $2.8 \mathrm{Kg} / \mathrm{cm}^{2}$. All experiments were conducted at room temperature.

\subsection{Determination of Total Phenols and Flavonoids}

The method of Boestfleisch et al. [20] was followed. Leaves dry were incubated (10 min) in methanol ( $80 \%)$ with continuous shaking. Subsequently, samples obtained in saline conditions were centrifugation for $5 \mathrm{~min}$ at $15,000 \times \mathrm{g}$ and the supernatant was collected.

The quantification of total phenols was performed following the protocols by Dudonné et al. [83]. One hundred $\mu \mathrm{L}$ of water was pipetted into small tubes. Then 
were added: blank ( $80 \%$ methanol), or gallic acid standard $\left(5-250 \mu \mathrm{gL}^{-1}\right)$ or $10 \mu \mathrm{L}$ of methanolic extract. The reaction is completed with Folin-Ciocalteu reagent $(10 \mu \mathrm{L})$. After waiting $8 \mathrm{~min}$ sodium carbonate $(7 \%)(100 \mu \mathrm{L})$ was added. In the dark and room temperature, tubes were incubated for approximately 90-100 $\mathrm{min}$. Total phenols were calculated using a standard curve. The samples at wavelength of $765 \mathrm{~nm}$ were measured in a spectrophotometer VARIAN Cary 4000 UV-VIS (Santa Clara, CA, USA).

The quantification of the total flavonoids was performed following Dewanto et al. [84]. In this case, in each tube was added $150 \mu \mathrm{L}$ of water. Then we added blank (80\% methanol), or catechin hydrate standard $\left(0-400 \mu \mathrm{g} \mathrm{mL} \mathrm{L}^{-1}\right)$, or $25 \mu \mathrm{L}$ of methanolic extract, and $\mathrm{NaNO}_{3}$ $(3.75 \%)(10 \mu \mathrm{L})$. After waiting $6 \mathrm{~min}$, the reaction was completed with $\mathrm{AlCl}_{3}(10 \%)(15 \mu \mathrm{L})$. After 5 min of incubation, $\mathrm{NaOH}(1 \mathrm{M})(50 \mu \mathrm{L})$ was added. Total flavonoids were calculated from a standard curve. The samples and the curve standard at wavelength $510 \mathrm{~nm}$. were measured in a spectrophotometer VARIAN Cary 4000 UVA-VIS (Santa Clara, CA, USA).

\subsection{Analysis of Free, Bound and Conjugated Polyamines}

For PAs extraction the method followed by Ghabriche et al. [54] was used with minor modifications. Dry leaf samples (in saline and non-saline conditions) were ground in a mortar and homogenized with $\mathrm{HCl}(1 \mathrm{M})(v / v)$, then centrifuged at $23,000 \times g$ at $4{ }^{\circ} \mathrm{C}$ for $20 \mathrm{~min}$. The supernatant was used to determine free polyamines by dansylation method [85]. The samples were resuspended in methanol $(1 \mathrm{~mL})$ and then centrifuged at $13,000 \times \mathrm{g}$ for $15 \mathrm{~min}$. Later, these samples needed to be filtered using microfilters (Chromafil PES-45/15, $0.45 \mu \mathrm{m}$; Macherey-Nagel). Twenty $\mu \mathrm{L}$ were injected into a Bio-Rad HPLC system (Hercules, CA, USA) equipped with a Nucleosil 100-5 C18MN 250/04 column (particle size: $5 \mu \mathrm{m}, 4.6 \times 250 \mathrm{~mm}^{2}$ ). The conditions of HPLC to quantify the integration peaks were the following: a methanol/water stepped gradient program changing from $60 \%$ to $100 \%$ methanol over $25 \mathrm{~min}$, flow rate $1 \mathrm{~mL} \mathrm{~min}^{-1}$, and temperature of $35^{\circ} \mathrm{C}$. A Shimadzu RF-10Axl fluorimeter detector (excitation wavelength $320 \mathrm{~nm}$ and emission wavelength $510 \mathrm{~nm}$ ) was used to determine dansylated free polyamines.

Bound forms (covalently bound to macromolecules such as proteins) and conjugated forms (covalently bound with small molecules such as hydroxycinnamic acids) were also analyzed. We added $200 \mu \mathrm{L}$ of HCL $(12 \mathrm{~N})$ to the same amount of supernatant $(200 \mu \mathrm{L})$ and transferred to dark tightly capped glass tubes. These tubes were placed in a heater and heated at $110{ }^{\circ} \mathrm{C}$ for $24 \mathrm{~h}$ to realize sample hydrolysis. After $\mathrm{HCl}$ was evaporated, the residue was resuspended in $200 \mu \mathrm{L}$ of perchloric acid $(10 \%)$ and used for dansylation. The pellet was used to extract bound PAs. This was dissolved in $5 \mathrm{~mL}$ of $\mathrm{NaOH}(1 \mathrm{~N})$. The mixture was centrifuged at $23,000 \times g$ at $4{ }^{\circ} \mathrm{C}$ for $20 \mathrm{~min}$., and the supernatant was hydrolysed and dansylated under the same conditions described above. Dansylated free PAs (supernatant), dansylated conjugated PAs (supernatant hydrolysed) and dansylated bound PAs (pellet hydrolysed) were injected $(20 \mu \mathrm{L})$ in the HPLC, in addition to PA standards (Put, Spd, Spm from Sigma, San Francisco, CA, USA), for quantification.

\subsection{Ethylene Production}

The method of Bueno et al. [86] was followed: fresh leaves collected of $P$. coronopus (45-day-old) were immediately transferred into a $5 \mathrm{~mL}$ flask (containing at the bottom filter paper and $50 \mu \mathrm{L}$ of distilled water). All flasks were sealed with a silicone-rubber stopper (to prevent gas leakage). Flasks were incubated on a stove for $1 \mathrm{~h}$ incubation period, at $30^{\circ} \mathrm{C}$ in darkness. Later, a $1 \mathrm{~mL}$ gas sample was injected into a HP 5890 series II, Hewlett Packard (Palo Alto, CA, USA) gas chromatograph fitted with a flame ionization detector and a $2 \mathrm{~m} \times 4 \mathrm{~mm}$ stainless-steel column packed with 50-80 mesh Poropack- $\mathrm{R}$. The conditions of chromatograph were: $\mathrm{N}_{2}, \mathrm{H}_{2}$ and synthetic air flow rates 50, 86, and $400 \mathrm{~mL} \mathrm{~min}{ }^{-1}$, respectively. To analyze and quantify ethylene production, peaks integration was compared with the retention time of ethylene $\left(\mathrm{C}_{2} \mathrm{H}_{4}\right)$ standard, (purity 99.9\%). 


\subsection{Data Analysis}

A randomized block design was used in our experiments. Data are presented as mean \pm standard error (SE). A Statgraphics Centurion v. 17 (University of Jaén) was used to perform analyses of variance (ANOVA). Significant differences between means were determined using Tukey's multiple range test $(p \leq 0.05$ and $p \leq 0.01)$. All parameters in the absence or presence of salt were compared using Pearson's correlation coefficients.

\section{Conclusions}

Halophyte cultivation as a part of biosaline agriculture could help improve productivity and crop quality and be used to restore saline and degraded land. In P. coronopus cultivation, exogenous Spd application $(0.5 \mathrm{mM})$ to the nutritive solution can improve growth and increase salt-stress tolerance, as well as increasing the osmolyte (sorbitol) and antioxidant compounds (phenols and flavonoids) under saline conditions. The increase in the endogenous PA pool, especially Spd and Spm (bound forms), is probably related to the protection of subcellular structures, the maintenance of photosynthetic activity, osmotic adjustment, ionic homeostasis and the improvement of antioxidant activity. In addition, the increase in Spd levels showed a negative correlation with ethylene, indicating than the decrease in ethylene also can contribute to PA accumulation. Auxins, CKs, GAs and SA pretreatments stimulated growth under non-saline conditions, but these PGRs were unable to mitigate the adverse effects of stress. Therefore, Spd application is the best pretreatment for $P$. coronopus cultivation and can contribute to improving the tolerance to salinity and nutritional quality of this halophyte, although it will be necessary to research in each halophyte which is the better treatment to apply.

Author Contributions: Conceptualization, M.d.P.C. and M.B.; methodology, M.d.P.C. and M.B.; software, M.d.P.C. and M.B.; validation, M.d.P.C. and M.B.; formal analysis, M.d.P.C. and M.B.; investigation, M.d.P.C. and M.B.; resources, M.B.; data curation, M.d.P.C. and M.B.; writing-original draft preparation, M.B.; writing-review and editing, M.B.; visualization, M.d.P.C. and M.B.; supervision, M.d.P.C. and M.B.; project administration, M.d.P.C.; funding acquisition, M.d.P.C. All authors have read and agreed to the published version of the manuscript.

Funding: This research was funded by Spanish Ministry of Science and Innovation, grant number CGL2006-08830, The involvement of growth regulators in plant response to salinity.

Acknowledgments: We want to thank the Technical Research Services of the University of Jaén for their invaluable help in the quantification of metabolites (sorbitol, polyamines, and ethylene). Our thanks to the designer Sonia Reyes for her valuable help in preparing high-quality tables, graphics, and photographs.

Conflicts of Interest: The authors declare no conflict of interest.

\section{References}

1. Thornton, P.K.; Ericksen, P.J.; Herrero, M.; Challinor, A.J. Climate variability and vulnerability to climate change: A review. Glob. Chang. Biol. 2014, 20, 3313-3328. [CrossRef]

2. Leisner, C.P. Review: Climate change impacts on food security-focus on perennial cropping systems and nutritional value. Plant Sci. 2020, 293, 110412. [CrossRef]

3. Shahzad, A.; Ullah, S.; Dar, A.A.; Sardar, M.F.; Mehmood, T.; Tufail, M.A.; Shakoor, A.; Haris, M. Nexus on climate change: Agriculture and possible solution to cope future climate change stress. Environ. Sci. Pollut. Res. Int. 2021, 28, 14211-14232. [CrossRef]

4. Santos, J.; Al-Azzawi, M.; Aronson, J.; Flowers, T.J. eHALOP a database of salt-tolerant plants: Helping put halophytes to work. Plant Cell Physiol. 2016, 57, e10. [CrossRef]

5. Grigore, M.N. Definition and classification of halophytes as an ecological group of plants. In Handbook of Halophytes: From Molecules to Ecosystems towards Biosaline Agriculture, 1st ed.; Grigore, M.N., Ed.; Springer: Cham, Switzerland, 2021; pp. 1-48. [CrossRef]

6. Gul, B.; Ansari, R.; Flowers, T.J.; Khan, M.A. Germination strategies of halophyte seeds under salinity. Environ. Exp. Bot. 2013, 92, 4-18. [CrossRef]

7. Kumari, A.; Das, P.; Parida, A.K.; Agarwal, P.K. Proteomics, metabolomics, and ionomics perspectives of salinity tolerance in halophytes. Front. Plant Sci. 2015, 6, 537. [CrossRef] 
8. Bueno, M.; Cordovilla, M.P. Ecophysiology and uses of halophytes in diverse habitats. In Handbook of Halophytes: From Molecules to Ecosystems towards Biosaline Agriculture, 1st ed.; Grigore, M.N., Ed.; Springer: Cham, Switzerland, 2021; pp. 1-25. [CrossRef]

9. Grigore, M.N.; Toma, C. Integrative anatomy of halophytes from Mediterranean climate. In Handbook of Halophytes: From Molecules to Ecosystems towards Biosaline Agriculture, 1st ed.; Grigore, M.N., Ed.; Springer: Cham, Switzerland, 2021; pp. 1-35. [CrossRef]

10. Shaid, M.A.; Sarkhosh, A.; Khan, N.; Balal, R.M.; Ali, S.; Rossi, L.; Gómez, C.; Mattson, N.; Nasim, W.; García-Sánchez, F. Insights into physiological and biochemical impacts of salt stress on plant growth and development. Agronomy 2020, 10, 938. [CrossRef]

11. Borsai, O.; Al Hassan, M.; Negrusier, C.; Raigón, M.D.; Boscaiu, M.; Sestraş, R.E.; Vicente, O. Responses to salt stress in Portulaca: Insight into its tolerance mechanism. Plants 2020, 9, 1660. [CrossRef]

12. Panta, S.; Flowers, T.; Lane, P.; Doyle, R.; Haros, G.; Shabala, S. Halophyte agriculture: Success stories. Environ. Exp. Bot. 2014, 107, 71-83. [CrossRef]

13. Atzori, G. The potential of edible halophytes as new crops in saline agriculture. The ice plant (Mesembryanthemum crystallinum L.) case study. In Future of Sustainable Agriculture in Saline Environments, 1st ed.; CRC Press: Boca Raton, NY, USA, 2021; pp. 443-460. [CrossRef]

14. Nikalje, G.C.; Srivastava, A.K.; Pandey, G.K.; Suprasanna, P. Halophytes in biosaline agriculture: Mechanism, utilization, and value addition. Land Degrad. Dev. 2018, 29, 1081-1095. [CrossRef]

15. Christiansen, A.H.C.; Lyra, D.A.; Jørgensen, H. Increasing the value of Salicornia bigelovii green biomass grown in a desert environment through biorefining. Ind. Crops Prod. 2021, 160, 113105. [CrossRef]

16. Duarte, B.; Caçador, I. Iberian halophytes as agroecological solutions for degraded lands and biosaline agriculture. Sustainability 2021, 13, 1005. [CrossRef]

17. Shaygan, M.; Mulligan, D.; Baumgartl, T. The potential of three halophytes (Tecticornia pergranulata, Sclerolaena longicuspis, and Frankenia serpyllifolia) for the rehabilitation of brine-affected soils. Land Degrad. Dev. 2018, 29, 2002-2014. [CrossRef]

18. Hasanuzzaman, M.; Nahar, K.; Alam, M.M.; Bhowmik, P.C.; Hossain, M.A.; Rahman, M.M.; Vara Prasad, M.N.; Ozturk, M.; Fujita, M. Potential use of halophytes to remediate saline soils. BioMed Res. Int. 2014, 2014, 589341. [CrossRef] [PubMed]

19. Jesus, J.M.; Danko, A.S.; Fiúza, A.; Borges, M.T. Phytoremediation of salt-affected soils: A review of processes, applicability, and the impact of climate change. Environ. Sci. Poll. Res. 2015, 22, 6511-6525. [CrossRef]

20. Boestfleisch, C.; Wagenseil, N.B.; Buhmann, A.K.; Seal, C.E.; Wade, E.M.; Muscolo, A.; Papenbrock, J. Manipulating the antioxidant capacity of halophytes to increase their cultural and economic value through saline cultivation. AoB Plants 2014, 6, plu046. [CrossRef]

21. Zheng, L.; Ma, H.; Jiao, Q.; Ma, C.; Wang, P. Phytohormones: Important participators in plant salt tolerance. Intl. J. Agric. Biol. 2020, 24, 319-332. [CrossRef]

22. Ashfaq, M.; Khan, S. Role of phytohormones in improving the yield of oilseed crops. In Oils Seed Crops: Yield and Adaptation under Environmental Stress, 1st ed.; Ahmad, P., Ed.; John Wiley \& Sons Ltd.: Hoboken, NJ, USA, 2017; Volume 9, pp. 165-183. [CrossRef]

23. Llanes, A.; Reginato, M.; Devinar, G.; Luna, V. What is known about phytohormones in halophytes? A review. Biologia 2018, 73, 727-742. [CrossRef]

24. Szepesi, A. Halotropism: Phytohormonal aspects and potential applications. Front. Plant Sci. 2020, 11, 571025. [CrossRef] [PubMed]

25. Berková, V.; Kameniarová, M.; Ondrisková, V.; Berka, M.; Menšiková, S.; Kopecká, R.; Luklová, M.; Novák, J.; Spichal, L.; Rashotte, A.M.; et al. Arabidopsis response to inhibitor of cytokinin degradation INCYDE: Modulations of cytokinin signaling and plant proteome. Plants 2020, 9, 1563. [CrossRef]

26. Fahad, S.; Hussain, S.; Matloob, A.; Khan, F.A.; Khaliq, A.; Saud, S.; Hassan, S.; Shan, D.; Khan, F.; Ullah, N.; et al. Phytohormones and plant responses to salinity stress: A review. Plant Growth Regul. 2015, 75, 391-404. [CrossRef]

27. Marković, M.; Momcilov, T.; Uzelac, B.; Cingel, A.; Milošević, S.; Jevremović, S.; Subotić, A. Breaking the dormancy of snake's head fritillary (Fritillary meleagris L.) in vitro bulbs-Part 1: Effect of $\mathrm{GA}_{3}$, GA inhibitors and temperature on fresh weight, sprouting and sugar content. Plants 2020, 9, 1449. [CrossRef]

28. Liu, J.H.; Wang, W.; Wu, H.; Gong, X.; Moriguchi, T. Polyamines function in stress tolerance: From synthesis to regulation. Front. Plant Sci. 2015, 6, 827. [CrossRef] [PubMed]

29. Alcázar, R.; Bueno, M.; Tiburcio, A.F. Polyamines: Small amines with large effects on plant abiotic stress tolerance. Cells 2020, 9 , 2373. [CrossRef] [PubMed]

30. Azad, N.; Rezayian, M.; Hassanpour, H.; Nikman, V.; Ebrahimzadeh, H. Physiological mechanisms of salicylic acid in Mentha pulegium L. under salinity and drought stress. Braz. J. Bot. 2021, 44, 359-369. [CrossRef]

31. Jayakannan, M.; Bose, J.; Babourina, O.; Rengel, Z.; Shabala, S. Salicylic acid in plant salinity stress signalling and tolerance. Plant Growth Regul. 2015, 76, 25-40. [CrossRef]

32. Bueno, M.; Lendínez, M.L.; Calero, J.; Cordovilla, M.P. Salinity responses of three halophytes from inland saltmarshes of Jaén (southern Spain). Flora 2020, 266, 151589. [CrossRef]

33. Consejería del Medio Ambiente. Flora Vascular de Andalucía Oriental; Junta de Andalucía: Sevilla, Spain, 2009.

34. Al Hassan, M.; Pacurar, A.; López-Gresa, M.P.; Donat-Torres, M.P.; Llinares, J.V.; Boscaiu, M.; Vicente, O. Effects of salt stress on three ecologically distinct Plantago species. PLoS ONE 2016, 11, e0160236. [CrossRef]

35. Koyro, H.W. Effect of salinity on growth, photosynthesis, water relations and solute compositions of the potential cash crop halophyte Plantago coronopus (L.). Environ. Exp. Bot. 2006, 56, 136-146. [CrossRef] 
36. Ltaeif, H.B.; Sakhraoui, A.; González-Orenga, S.; Faz, A.L.; Boscaiu, M.; Vicente, O.; Rouz, S. Responses to salinity in four Plantago species from Tunisia. Plants 2021, 10, 1392. [CrossRef] [PubMed]

37. Jdey, A.; Falleh, H.; Ben Jannet, S.; Mkadmini Hammi, K.; Dauvergne, X.; Ksouri, R.; Magné, C. Phytochemical investigation and antioxidant, antibacterial and anti-tyrosinase performances for six medicinal halophytes. South Afr. J. Bot. 2017, 112, 508-514. [CrossRef]

38. Petropoulos, S.A.; Karkanis, A.; Martins, N.; Ferreira, I.C. Edible halophytes of the Mediterranean basin: Potential candidates for novel food products. Trends Food Sci. Technol. 2018, 74, 69-84. [CrossRef]

39. Ceccanti, C.; Brizzi, A.; Landi, M.; Incrocci, L.; Pardossi, A.; Guidi, L. Evaluation of major minerals and trace elements in wild and domesticated edible herbs traditionally used in the Mediterranean area. Biol. Trace Elem. Res. 2021, 199, 3553-3561. [CrossRef]

40. Puccinelli, M.; Pezzarossa, B.; Pintimalli, L.; Malorgio, F. Selenium biofortification of three wild species, Rumex acetosa L., Plantago coronopus L., and Portulaca oleracea L., grown as microgreens. Agronomy 2021, 11, 1155. [CrossRef]

41. Ceccanti, C.; Landi, M.; Incrocci, L.; Pardossi, A.; Venturi, F.; Taglieri, I.; Ferroni, G.; Guidi, L. Comparison of three domestications and wild-harvested plants for nutraceutical properties and sensory profiles in five wild edible herbs: Is domestication possible? Foods 2020, 9, 1065. [CrossRef]

42. Amir, R.; Munir, F.; Khan, M.; Iqbal, T. Use of plant hormones for the improvement of plant growth and production under salt stress. In Salt Stress, Microbes, and Plant Interactions: Causes and Solution, 2nd ed.; Akhtar, M.S., Ed.; Springer Nature: Singapore, 2019; Volume 1, pp. 59-90. [CrossRef]

43. Morsi, M.M.; Abdelmigid, H.M.; Aljoudi, N.G.S. Exogenous salicylic acid ameliorates the adverse effects of salt stress on antioxidant system in Rosmarinus officinalis L. Egypt. J. Bot. 2018, 58, 249-263. [CrossRef]

44. Islam, M.J.; Ryu, B.R.; Azad, M.O.K.; Rahman, M.H.; Rana, M.S.; Lim, J.D.; Lim, Y.S. Exogenous putrescine enhances salt tolerance and ginsenosides content in Korena ginseng (Panax ginseng Meyer) sprouts. Plants 2021, 10, 1313. [CrossRef]

45. Tounekti, T.; Hernández, I.; Müller, M.; Khemira, H.; Munné-Bosch, S. Kinetin applications alleviate salt stress and improve the antioxidant composition of leaf extracts in Salvia officinalis. Plant Physiol. Biochem. 2011, 49, 1165-1176. [CrossRef]

46. Li, S.; Jin, H.; Zhang, Q. The effect of exogenous spermidine concentration on polyamine metabolism and salt tolerance in zoysiagrass (Zoysia japonica Steud) subjected to short-term salinity stress. Front. Plant Sci. 2016, 7, 1221. [CrossRef] [PubMed]

47. Tiburcio, A.F.; Altabella, T.; Bitrián, M.; Alcázar, R. The roles of polyamines during the lifespan of plants: From development to stress. Planta 2014, 240, 1-18. [CrossRef] [PubMed]

48. Kamiab, F.; Tavassolian, I.; Hosseinifarahi, M. Biologia Futura: The role of polyamine in plant science. Biol. Futur. 2020, 71, 183-194. [CrossRef]

49. Filgueiras, C.C.; Martins, A.D.; Pereira, R.V.; Willett, D.S. The ecology of salicylic acid signaling: Primary, secondary and tertiary effects with application in agriculture. Int. J. Mol. Sci. 2019, 20, 5851. [CrossRef]

50. Li, S.M.; Zheng, H.X.; Zhang, X.S.; Sui, N. Cytokinins as central regulators during plant growth and stress response. Plant Cell Rep. 2021, 40, 271-282. [CrossRef]

51. Chen, D.; Shao, Q.; Yin, L.; Younis, A.; Zheng, B. Polyamine function in plants: Metabolism, regulation on development, and roles in abiotic stress responses. Front. Plant Sci. 2019, 9, 1945. [CrossRef]

52. Pottosin, I.; Shabala, S. Polyamines control of cation transport across plant membranes: Implications for ion homeostasis and abiotic stress signaling. Front. Plant Sci. 2014, 5, 154. [CrossRef] [PubMed]

53. Pál, M.; Szalai, G.; Janda, T. Speculation: Polyamines are important in abiotic stress signaling. Plant Sci. 2015, 237, 16-23. [CrossRef] [PubMed]

54. Ghabriche, R.; Ghnaya, T.; Mnasri, M.; Zaier, H.; Baioui, R.; Vromman, D.; Abdelly, C.; Lutts, S. Polyamine and tyramine involvement in $\mathrm{NaCl}$-induced improvement of $\mathrm{Cd}$ resistance in the halophyte Inula crithmoides L. J. Plant Physiol. 2017, 216, 136-144. [CrossRef]

55. Ruiz-Carrasco, K.; Antognoni, F.; Coulibaly, A.K.; Lizardi, S.; Covarrubias, A.; Martínez, E.A.; Molina-Montenegro, M.A.; Biondi, S.; Zurita-Silva, A. Variation in salinity tolerance of four lowland genotypes of quinoa (Chenopodium quinoa Willd.) as assessed by growth, physiological traits, and sodium transporter gene expression. Plant Physiol. Biochem. 2011, 49, 1333-1341. [CrossRef]

56. Ruiz, K.B.; Rapparini, F.; Bertazza, G.; Silva, H.; Torrigiani, P.; Biondi, S. Comparing salt-induced responses at the transcript level in a salares and coastal-lowlands landrace of quinoa (Chenopodium quinoa Willd.). Environ. Exp. Bot. 2017, 139, 127-142. [CrossRef]

57. Zarranz Elso, M.; García-Jiménez, P.; Robaina, R.R. Endogenous polyamine content and photosynthetic performance under hypo-osmotic conditions reveal Cymodocea nodosa as an obligate halophyte. Aquat. Biol. 2012, 17, 7-17. [CrossRef]

58. Gharbi, E.; Martínez, J.P.; Benahmed, H.; Fauconnier, M.L.; Lutts, S.; Quinet, M. Salicylic acid differently impacts ethylene and polyamine synthesis in the glycophyte Solanum lycopersicum and the wild-related halophyte Solanum chilense exposed to mild salt stress. Physiol. Plant 2016, 158, 152-167. [CrossRef] [PubMed]

59. Zapata, P.J.; Serrano, M.; García-Legaz, M.F.; Pretel, M.T.; Botella, M.A. Short term effect of salt shock on ethylene and polyamines depends on plant salt sensitivity. Front. Plant Sci. 2017, 8, 855. [CrossRef] [PubMed]

60. Minocha, R.; Majumdar, R.; Minocha, S.C. Polyamines and abiotic stress in plants: A complex relationship. Front. Plant Sci. 2014, 5, 175. [CrossRef] [PubMed]

61. Pardo-Domènech, L.L.; Tifrea, A.; Grigore, M.N.; Boscaiu, M.; Vicente, O. Proline and glycine betaine accumulation in two succulent halophytes under natural and experimental conditions. Plant Biosyst. 2016, 150, 904-915. [CrossRef] 
62. Pottosin, I.; Velarde-Buendía, A.M.; Bose, J.; Fuglsang, A.T.; Shabala, S. Polyamines cause plasma membrane depolarization, activate $\mathrm{Ca}^{2+}$, and modulate $\mathrm{H}^{+}$-ATPase pump activity in pea roots. J. Exp. Bot. 2014, 65, 2463-2472. [CrossRef] [PubMed]

63. Pottosin, I.; Olivas-Aguirre, M.; Dobrovinskaya, O.; Zepeda-Jazo, I.; Shabala, S. Modulation of ion transport across plant membranes by polyamines: Understanding specific modes of action under stress. Front. Plant Sci. 2021, 11, 616077. [CrossRef]

64. Kaur, G.; Asthir, B. Proline: A key player in plant abiotic stress tolerance. Biol. Plant. 2015, 59, 609-619. [CrossRef]

65. Ozgur, R.; Uzilday, B.; Sekmen, A.H.; Turkan, I. Reactive oxygen species regulation and antioxidant defence in halophytes. Funct. Plant Biol. 2013, 40, 832-847. [CrossRef]

66. Slama, I.; Abdelly, C.; Bouchereau, A.; Flowers, T.; Savouré, A. Diversity, distribution, and roles of osmoprotective compounds accumulated in halophytes under abiotic stress. Ann. Bot. 2015, 115, 433-447. [CrossRef]

67. Anwar, R.; Mattoo, A.K.; Avtar, K.H. Polyamine interactions with plant hormones: Crosstalk at several levels. In Polyamines: A Universal Molecular Nexus for Growth, Survival, and Specialized Metabolism, 1st ed.; Kusano, T., Suzuki, H., Eds.; Springer: Tokyo, Japan, 2015; pp. 267-302. [CrossRef]

68. Ksouri, R.; Megdiche, W.; Falleh, H.; Trabelsi, N.; Boulaaba, M.; Smaoui, A.; Abdelly, C. Influence of biological, environmental, and technical factors on phenolic content and antioxidant activities of Tunisian halophytes. Comptes Rendus Biol. 2008, 331, 865-873. [CrossRef]

69. Ksouri, R.; Ksouri, W.M.; Jallali, I.; Debez, A.; Magné, C.; Hiroko, I.; Abdelly, C. Medicinal halophytes: Potent source of health promoting biomolecules withy medical, nutraceutical and food applications. Crit. Rev. Biotechnol. 2012, 32, 289-326. [CrossRef] [PubMed]

70. Pereira, C.G.; Custódio, L.; Rodrigues, M.J.; Neng, N.R.; Nogueira, J.M.F.; Carlier, J.; Costa, M.C.; Varela, J.; Barreira, L. Profiling of antioxidant potential and phytoconstituents of Plantago coronopus. Braz. J. Biol. 2017, 77, 632-641. [CrossRef] [PubMed]

71. Barros, L.; Morales, P.; Carvalho, A.M.; Ferreira, I.C.F.R. Antioxidant potential of wild plant foods. In Mediterranean Wild Edible Plants: Ethnobotany and Food Composition Tables; Springer: New York, NY, USA, 2016; pp. 209-232. ISBN 978-1-49-393329-7.

72. Bueno, M.; Cordovilla, M.P. Polyamines in halophytes. Front. Plant Sci. 2019, 10, 439. [CrossRef] [PubMed]

73. Ioannidis, N.E.; Tsiavos, T.; Kotzabasis, K. Chemical bonding of chlorophylls and plant aminic axial ligands impact harvesting of visible light and quenching of fluorescence. Photochem. Photobiol. 2012, 88, 98-106. [CrossRef]

74. Sang, T.; Shan, X.; Li, B.; Shu, S.; Sun, J.; Guo, S. Comparative proteomic analysis reveals the positive effect of exogenous spermidine on photosynthesis and salinity tolerance in cucumber seedlings. Plant Cell Rep. 2016, 35, 1769-1782. [CrossRef]

75. Wu, Z.; Wang, J.; Yan, D.; Yuan, H.; Wang, Y.; He, Y.; Wang, X.; Li, Z.; Mei, J.; Hu, M.; et al. Exogenous spermidine improves salt tolerance of pecan-grafted seedlings via activating antioxidant system and inhibiting the enhancement of $\mathrm{Na}^{+} / \mathrm{K}^{+}$ratio. Acta Physiol. Plant. 2020, 42, 83. [CrossRef]

76. Jiang, D.; Hou, J.; Gao, W.; Tong, X.; Li, M.; Chu, X.; Chen, G. Exogenous spermidine alleviates the adverse effects of aluminium toxicity on photosystem II through improved antioxidant system and endogenous polyamine contents. Ecotoxicol. Environ. Saf. 2021, 207, 111265. [CrossRef]

77. Zhou, C.; Sun, Y.; Ma, S.; Wang, J. Heterologous expression of EsSPDS1 in tobacco plants improves drought tolerance with efficient reactive oxygen species scavenging systems. South Afr. J. Bot. 2015, 96, 19-28. [CrossRef]

78. Majumdar, R.; Barchi, B.; Turlapati, S.A.; Gagne, M.; Minocha, R.; Long, S.; Minocha, S.C. Glutamate, ornithine, arginine, proline, and polyamine metabolic interactions: The pathway is regulated at the post-transcriptional level. Front. Plant Sci. 2016, 7, 78 [CrossRef] [PubMed]

79. Lasanajak, Y.; Minocha, R.; Minocha, S.C.; Goyal, R.; Fatima, T.; Handa, A.K.; Mattoo, A.K. Enhanced flux of substrates into polyamine biosynthesis but not ethylene in tomato fruit engineered with yeast S-adenosylmethionine decarboxylase gene. Amino Acids 2014, 46, 729-742. [CrossRef]

80. Jia, T.; Hou, J.; Iqbal, M.Z.; Zhang, Y.; Cheng, B.; Feng, H.; Li, Z.; Liu, L.; Zhou, J.; Feng, G.; et al. Overexpression of the with clover TrSAMDC1 gene enhanced salt and drought resistance in Arabidopsis thaliana. Plant Physiol. Biochem. 2021, 165, 147-160. [CrossRef]

81. Hoagland, D.R.; Arnon, D.I. The water-culture method for growing plants without soil. Calif. Agric. Exp. Stn. Bull. 1950, 347, $1-32$.

82. Al Hassan, M.; López-Gresa, M.P.; Boscaiu, M.; Vicente, O. Stress tolerance mechanisms in Juncus: Responses to salinity and drought in three Juncus species adapted to different natural environments. Funct. Plant Biol. 2016, 43, 949-960. [CrossRef] [PubMed]

83. Dudonné, S.; Vitrac, X.; Coutière, P.; Woillez, M.; Mérillon, J.M. Comparative study of antioxidant properties and total phenolic content of 30 plant extracts of industrial interesting using DPPH, ABTS, FRAP, SOD, and ORAC assays. J. Agric. Food Chem. 2009, 57, 1768-1774. [CrossRef] [PubMed]

84. Dewanto, V.; Wu, X.; Adom, K.K.; Liu, R.H. Thermal processing enhances the nutritional value of tomatoes by increasing total antioxidant activity. J. Agric. Food Chem. 2002, 50, 3010-3014. [CrossRef] [PubMed]

85. Smith, M.A.; Davies, P.J. Separation and quantification of polyamines in plant tissue by high performance liquid chromatography of their dansyl derivatives. Plant Physiol. 1985, 78, 89-91. [CrossRef] [PubMed]

86. Bueno, M.; Lendínez, M.L.; Aparicio, C.; Cordovilla, M.P. Effect of salinity on polyamines and ethylene in Atriplex prostrata and Plantago coronopus. Biol. Plant. 2015, 59, 596-600. [CrossRef] 